\title{
Occurrence and Partial Characterization of a New Mechanically Transmissible Virus in Mashua from the Ecuadorian Highlands
}

\author{
S. L. Soria, Department of Plant and Soil Sciences, College of Agricultural Sciences, Delaware Agricultural Ex- \\ periment Station, University of Delaware, Newark, 19717; R. Vega, AMDE Corp., Ambato, Ecuador; V. D. Dam- \\ steegt, Foreign Disease and Weed Laboratory, USDA-ARS Fort Detrick, Frederick, MD; L. L. McDaniel, Ameri- \\ can Type Culture Collection, Rockville, MD; and S. L. Kitto and T. A. Evans, Department of Plant and Soil \\ Sciences, University of Delaware
}

\begin{abstract}
Soria, S. L., Vega, R., Damsteegt, V. D., McDaniel, L. L., Kitto, S. L., and Evans, T. A. 1998. Occurrence and partial characterization of a new mechanically transmissible virus in mashua from the Ecuadorian Highlands. Plant Dis. 82:69-73.

Mashua (Tropaeolum tuberosum) is a tuber crop indigenous to the Andean highlands and of economic value to its native people as a food and medicinal crop. Field plants often exhibit symptoms typical of virus infection, including interveinal chlorosis, leaf cupping, distortion, and stunting. Using an herbaceous host range, at least 1 mechanically transmissible virus was detected in each of 10 accessions. All virus isolates tested reacted to potyvirus group antiserum in indirect enzyme-linked immunosorbent assays (ELISA). Results of monoclonal antibody testing using antigen coated plate (ACP) ELISA, where virions are disrupted to expose cryptotopes, indicated that isolate $\mathrm{Tt} 4$ has epitopes in common with maize dwarf mosaic potyvirus $\mathrm{A}$ (MDMV-A). Polyclonal antiserum produced to purified preparations of the $\mathrm{Tt} 4$ isolate reacted in indirect ELISA to Tt 4, the common strain of potato potyvirus Y (PVY-C), less strongly to tobacco etch potyvirus (TEV) and potato potyvirus A (PVA), but not to 11 other potyviruses, including MDMV-A. Conversely, the Tt 4 isolate reacted strongly in indirect ELISA to antisera to bean common mosaic potyvirus (BCMV) and watermelon mosaic potyvirus 2 (WMV-2), but not antisera to 12 other potyviruses. Our data suggest that isolate $\mathrm{Tt} 4$ is a distinct potyvirus closely related to and sharing external epitopes with PVY-C, TEV, PVA, WMV-2, and BCMV, and buried epitopes with MDMV-A. The virus has been tentatively named Tropaeolum mosaic potyvirus (TropMV). A survey of T. tuberosum in Ecuador revealed that TropMV was widespread, being detected by ACP-ELISA in 34 of 46 accessions at the National Institute for Agricultural Research's Santa Catalina Research Station, Quito, and all eight production fields surveyed.
\end{abstract}

Mashua, also known as isanu, cubio, or anu (Tropaeolum tuberosum Ruiz \& Pavon) is one of the lost crops of the Inca and currently ranks fourth in importance among root crops of the Andean region after potato, oca, and ulluco (10). Mashua is often grown in a multicrop system along with other crops, and is a hardy plant that is often the prevalent root crop in the poorest regions where pesticides and fertilizers are too costly to use (Fig. 1). In the past, mashua tubers could be found in almost any rural Andean market. Mashua (pronounced mah-shoo-ah) is closely re-

Corresponding author: T. A. Evans

E-mail: tom.evans@mvs.udel.edu

This research was supported by the United States Agency for International Development, Program in Science and Technology Cooperation 12.187.

Published as Paper Number 1610 in the Journal Series of the Delaware Agricultural Experiment Station.

Accepted for publication 17 September 1997.

Publication no. D-1997-1030-01R

(C) 1998 The American Phytopathological Society lated to the garden nasturtium (Tropaeolum majus L.) and has been cultivated for its tubers by the people of the Andean highlands since Incan time. Among Andean tubers, mashua is one of the highest yielding, easiest to grow, and most tolerant of cold temperatures. It also repels many insects, nematodes, and other pathogens, making it a valuable plant for intercropping. Despite its potential productivity and pest resistance, mashua is not widely commercialized.

Tubers of mashua are the size of small potatoes, with shapes ranging from conical to carrot-like, and colors from yellow to purple to red (Fig. 2). Eaten raw, some have a peppery taste reminiscent of hot radishes. When boiled they become mild and, in some instances, sweet. Tubers are usually boiled with meat to form a stew or eaten as baked or fried vegetables. In New Zealand, where the plant has been newly introduced, mashua sets tubers well in open fields during a normal spring-to-autumn growing season (10). Mashua is a nutritious root crop with $20 \%$ solids, and protein as much as $16 \%$ of the dry matter (10).

The occurrence of viruses in mashua affects productivity (10). Over the past 10 years, the number of hectares of mashua planted and yield per hectare have both decreased drastically, and this reduced productivity has been cited as a reason for reduced interest in growing mashua (10). Field plants exhibit virus-like symptoms, which include smaller leaves with cupping, distortion, and interveinal chlorosis. Plants exhibiting any of these symptoms generally were thought to be infected with at least one mechanically transmissible virus (personal observation). Worldwide, a number of viruses have been reported to infect mashua's close relative, garden nasturtium $(2,3)$. Nasturtium ringspot virus appears to be closely related to broad bean wilt virus (6) and has been detected in California (7) and Brazil (13). Other viruses detected in $T$. majus include cabbage black ringspot tymovirus (14), beet curly top geminivirus (12), cucumber mosaic cucumovirus (11), pea early browning tobravirus (1), and tobacco rattle tobravirus (16). Only a single virus disease, mosaic, has been reported in T. tuberosum in Bolivia (4). Plants typically exhibited symptoms which included a mosaic and mal-

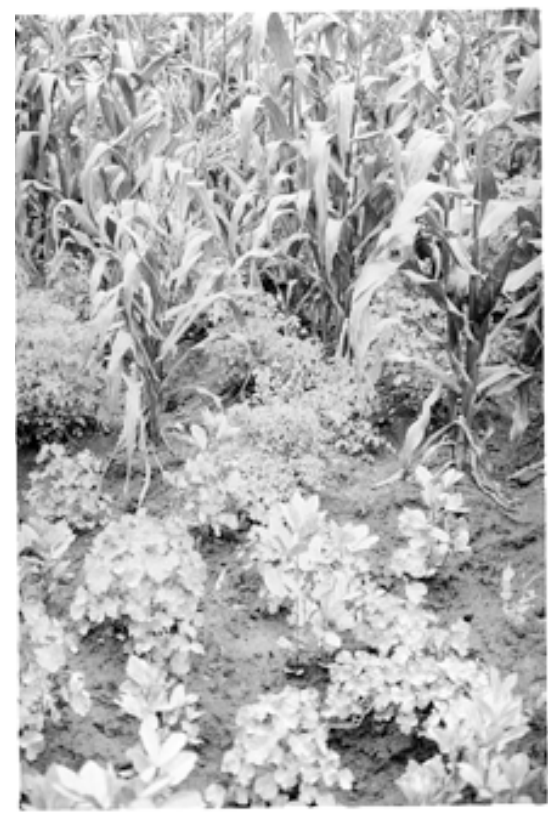

Fig. 1. Mashua (Tropaeolum tuberosum; foreground) is often grown in a multicrop-system along with other crops such as corn (Zea mays; background). 
formation of leaves. Based on leaf dip preparations, the causal virus was reported to be a flexuous rod with a mean length of $800 \mathrm{~nm}$, but no serological work was reported.

The objective of the present research was to isolate and characterize the causal virus of this mosaic disease of mashua, and to determine its incidence within mashua plantings in the highlands of Ecuador.

\section{MATERIALS AND METHODS}

Host range. Initially, 10 mashua accessions (ECU 1145, ECU 1141, ECU 1084, ECU 1093, ECU 1115, ECU 1101, ECU 1102, ECU 1096, ECU 1147, and ECU 1098) were introduced as tubers to the quarantine greenhouse at United States Department of Agriculture Agricultural Research Station (USDA-ARS) Fort Detrick, Frederick, Maryland from the Ecuadorian highlands under Animal and Plant Health Inspection Service (APHISPPQ) permit. Ten virus isolates, 1 from each accession (Tt 1, Tt 2, Tt 3, Tt 4, Tt 5, Tt 6, Tt 7, Tt 8, Tt 9 and Tt 10) respectively, were established by mechanical inoculation onto selected herbaceous indicator plants (Table 1). Symptomatic leaf tissue was triturated in $0.1 \mathrm{M}$ sodium citrate buffer, $\mathrm{pH} 7.4$, and rub-inoculated onto leaves of indicator plants that first had been dusted with 600 mesh Carborundum. Plants were observed over a 6-week period for symptom development. Inoculated leaves of symptomless indicator plants were back-inoculated to Nicotiana benthamiana L., a systemic host that produces distinct vein clearing, downward curling of leaves and stem, and necrosis of leaves and stem tissue over a 2-week period, and Gomphrena globosa L., a bioas-

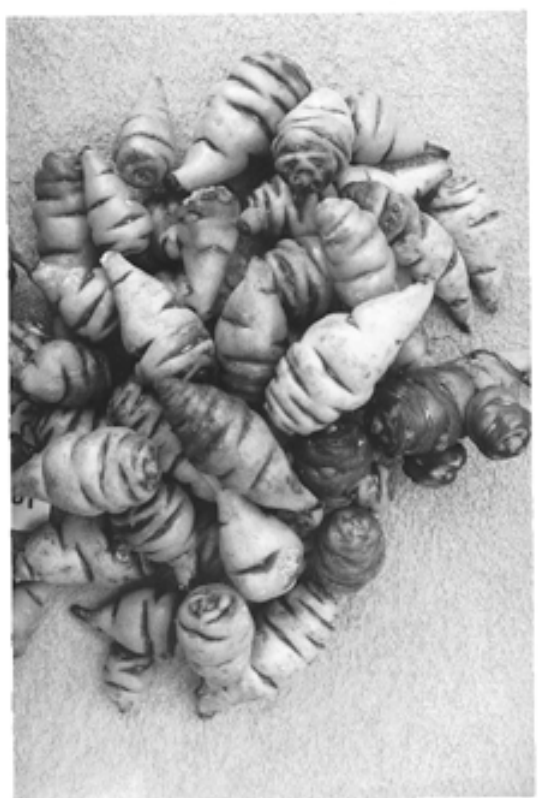

Fig. 2. The tubers of mashua (Tropaeolum tuberosum) are the size of small potatoes and often conically shaped. say host that produces red-rimmed local lesions with necrotic centers in 10 days, to test for latent infection. Isolates $\mathrm{Tt} 4 \mathrm{and} / \mathrm{or}$ Tt 9 were selected for further testing.

Physical properties. Longevity in vitro (LIV), thermal inactivation point (TIP), and dilution end-point (DEP) were determined for the $\mathrm{Tt} 4$ and $\mathrm{Tt} 9$ isolates using standard protocols (17). For TIP determination, systemically infected leaves of $N$. benthamiana in $0.1 \mathrm{M}$ sodium citrate

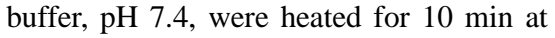
temperatures from 50 to $100^{\circ} \mathrm{C}$ at 10 -degree intervals using a heat-block. For LIV, crude sap prepared from $N$. benthamiana was held at $20^{\circ} \mathrm{C}$ in the dark for $0,1,5,7$, 14 , and 30 days. For DEP, crude sap was serially diluted with $0.1 \mathrm{M}$ sodium citrate buffer, $\mathrm{pH}$ 7.4. All samples were tested for infectivity using $N$. benthamiana plants.

Virus purification. The Tt 4 isolate was purified from systemically infected leaf tissue of $N$. benthamiana using a modification of the method developed by Hammond and Lawson (5) for potyviruses. Systemically infected leaf tissue (187 g) was triturated in liquid nitrogen, then homogenized in $1,000 \mathrm{ml}$ of $0.5 \mathrm{M}$ $\mathrm{K}_{2} \mathrm{H} / \mathrm{KH}_{2} \mathrm{PO}_{4}$ buffer, pH 8.4, with $0.5 \%$ (wt/vol) $\mathrm{Na}_{2} \mathrm{SO}_{3}$, and filtered through cheesecloth. The filtrate was centrifuged at $8,000 \times g$ for $10 \mathrm{~min}$ at $4^{\circ} \mathrm{C}$ in a GSA rotor and the supernatant collected. Triton X-100 was added to $2 \%$, and the solution stirred for $15 \mathrm{~min}$ at $4^{\circ} \mathrm{C}$. Polyethylene glycol
(PEG) 8000 was added to $6 \%$ and $\mathrm{NaCl}$ to $2 \%$, and the solution stirred for $1 \mathrm{~h}$ at $4^{\circ} \mathrm{C}$ and centrifuged at $10,000 \times g$ for $10 \mathrm{~min}$ at $4^{\circ} \mathrm{C}$ in a GSA rotor. Pellets were resuspended in $50 \mathrm{ml}$ of $100 \mathrm{mM}$ borate/KCl buffer, $\mathrm{pH}$ 8.0, and homogenized, transferred to a beaker, and stirred at least $1 \mathrm{~h}$ at $4^{\circ} \mathrm{C}$. A $25-\mathrm{ml}$ aliquot of the suspension was measured into R30 tubes, underlayed with $5 \mathrm{ml} /$ tube $30 \%$ (wt/vol) sucrose in $0.1 \mathrm{~m}$ borate/ $\mathrm{KCl}$ buffer, $\mathrm{pH} 8.0$, and centrifuged at $70,000 \times g$ for $2.5 \mathrm{~h}$ in an Ti50 rotor. Pellets were resuspended in either $100 \mathrm{mM}$ borate $/ \mathrm{KCl}$ buffer, $\mathrm{pH} 8.0$, or $10 \mathrm{mM}$ sodium phosphate buffer, $\mathrm{pH}$ 7.6. After centrifuging at $10,000 \times g$ for $10 \mathrm{~min}$ at $4^{\circ} \mathrm{C}$ for clarification, the suspensions were layered onto 10 to $40 \%$ sucrose gradients and centrifuged at $70,000 \times g$ for $2 \mathrm{~h}$ in a SW-41 rotor, and fractionated using an ISCO (ISCO Inc., Lincoln, NB) UA-5 ultraviolet fractionator at $258 \mathrm{~nm}$. Ultraviolet absorbing fractions were collected, pooled, and diluted 10-fold with borate/KCl buffer, $\mathrm{pH} 8.0$, or $10 \mathrm{mM}$ sodium phosphate buffer, $\mathrm{pH}$ 7.6, respectively, centrifuged at $70,000 \times g$ for $2.5 \mathrm{~h}$ in a Ti75 rotor, supernatant discarded, and pellets resuspended in $250 \mu \mathrm{l}$ of the same buffer.

Electron microscopy. The morphology of virions was determined by placing partially purified preparations of isolate $\mathrm{Tt} 4$, from the above procedure onto Formvarbacked, carbon-coated grids, staining them

Table 1. Host range of the potyvirus isolated from mashua (Tropaeolum tuberosum) in the highlands of Ecuador

\begin{tabular}{|c|c|}
\hline Test species & Reaction $^{\text {a }}$ \\
\hline Chenopodium quinoa & Red-rimmed local lesions with necrotic centers \\
\hline C. amaranticolor & Red-rimmed local lesions with necrotic centers \\
\hline Gomphrena globosa & Red-rimmed local lesions with necrotic centers \\
\hline Nicotiana debneyi & Chlorotic local lesions \\
\hline N. rustica & Chlorotic local lesions \\
\hline N. occidentalis & Dark-rimmed local lesions with necrotic centers \\
\hline N. benthamiana & $\begin{array}{l}\text { Systemic vein clearing, downward curling of leaves, } \\
\text { stem distortion, and necrosis of leaf and stem tissue }\end{array}$ \\
\hline \multicolumn{2}{|l|}{ Nicotiana tabacum } \\
\hline cv. Samsun & No reaction ${ }^{\mathrm{b}}$ \\
\hline cv. B-21 & No reaction \\
\hline cv. Havana & No reaction \\
\hline cv. Xanthi & No reaction \\
\hline \multicolumn{2}{|l|}{ Cucumis sativum } \\
\hline cv. National Pickling & No reaction \\
\hline \multicolumn{2}{|l|}{ Phaseolus vulgaris } \\
\hline cv. Top Crop & No reaction \\
\hline cv. Bountiful & No reaction \\
\hline cv. Pinto & No reaction \\
\hline cv. Blackturtle Soup & No reaction \\
\hline cv. Monroe & No reaction \\
\hline Capsicum annum & No reaction \\
\hline Brassica rapa & No reaction \\
\hline \multicolumn{2}{|l|}{ Vigna unguiculata } \\
\hline cv. California Blackeye & No reaction \\
\hline Amaranthus hybridus & No reaction \\
\hline \multicolumn{2}{|l|}{ Abelmoschus esculentus } \\
\hline cv. Clemson spineless & No reaction \\
\hline Lycopersicon esculentum & No reaction \\
\hline
\end{tabular}

${ }^{a}$ Isolates $\mathrm{Tt} 1, \mathrm{Tt} 2, \mathrm{Tt} 3, \mathrm{Tt} 4, \mathrm{Tt} 5, \mathrm{Tt} 6, \mathrm{Tt} 7, \mathrm{Tt} 8, \mathrm{Tt} 9, \mathrm{Tt} 10$ of Tropaeolum mosaic potyvirus (TropMV) gave identical reactions when mechanically inoculated to herbaceous hosts.

${ }^{\mathrm{b}}$ Inoculated leaves of asymptomatic indicator plants were triturated and inoculated onto leaves of $N$. benthamiana to test for latent infection. 
with $2 \%$ uranyl acetate or $2 \%$ phosphotungstic acid, and examining them with a Phillips 201 electron microscope at $80 \mathrm{kV}$. Two hundred particles were measured and particle size determined by comparison with photographs taken at the same magnification of germanium-shadowed carbon replicas made from diffraction gratings with 54,864 lines per inch, and/or grids containing purified preparations of tobacco mosaic tobamovirus as standard size markers.

Polyclonal antibodies and indirect enzyme-linked immunosorbent assay. Polyclonal antibodies were produced to highly purified preparations of the $\mathrm{Tt} 4$ isolate. Two rabbits were given intramuscular injections of $100 \mu \mathrm{g}$ of virus in Hunter's TiterMax (TiterMax, Inc., Atlanta, GA) adjuvant every 10 days. Test bleeds began 30 days after initial injection. Indirect enzyme-linked immunosorbent assay (ELISA) tests were carried out using purified $\gamma$ globulin to the $\mathrm{Tt} 4$ isolate and goat anti-rabbit $\gamma$-globulin conjugated with alkaline phosphatase (Sigma Chemical Co., St. Louis). Virus isolates Tt 4 and Tt 9 were tested in indirect ELISA against antiserum (Agdia Inc., Elkhart, IN) to the following potyviruses: watermelon mosaic potyvirus 1 (WMV-1), watermelon mosaic potyvirus 2 (WMV-2), potato potyvirus Ycommon strain (PVY-C), potato potyvirus A (PVA), pepper mild mottle potyvirus (PMMV), turnip mosaic potyvirus (TuMV), lettuce mosaic potyvirus (LMV), dasheen mosaic potyvirus (DaMV), soybean mosaic potyvirus (SMV), tobacco etch potyvirus (TEV), pea seedborne mosaic (PSMV), maize dwarf mosaic potyvirus $A$ (MDMV-A), and maize dwarf mosaic potyvirus B (MDMV-B). A positive threshold absorbance reading of four times the mean of the healthy control was used.

Monoclonal antibody panel. Twentysix monoclonal antibodies (MAbs) from a previous study (4), designated PTY MAbs, were used separately to compare the $\mathrm{Tt} 4$ and $\mathrm{Tt} 9$ isolates of the unknown potyvirus from mashua and other characterized potyviruses (courtesy R. Jordan and J. Hammond). Members of this panel of MAbs recognize epitopes that are (i) specific to bean yellow mosaic potyvirus (BYMV) strains, (ii) common to members of the BYMV subgroup, (iii) distinctive for unique potyviruses, or (iv) common to many distinct potyviruses $(9,10)$. The format is an indirect ELISA, with the viral antigen being coated directly onto the microtiter plate. These broad spectrum MAbs react with antigenic determinants on viral subunit regions not exposed on the virion surface. Virions were disrupted during the coating process to expose cryptotopes.

Antigen-coated plate enzyme-linked immunosorbent assays. Indexing of mashua tissue samples for the $\mathrm{Tt} 4$ and $\mathrm{Tt}$ 9 isolates was carried out using the PTY MAbs in indirect antigen-coated plates
(ACP) ELISA (10). One-gram composite samples of symptomatic leaves were triturated in $10 \mathrm{ml}$ of $0.05 \mathrm{M}$ sodium carbonate-bicarbonate buffer (CB) plus polyvinylpyrrolidone (PVP), $\mathrm{pH}$ 9.6, containing $0.2 \%$ sodium diethyldithiocarbamate (DIECA). The samples were incubated at room temperature for $2 \mathrm{~h}$ to disrupt virions, and $100 \mu \mathrm{l}$ of each sample dispensed to duplicate wells of Nunc MaxiSorp polystyrene ELISA plates. Plates were incubated for $1 \mathrm{~h}$ at room temperature, and washed three times with phosphate buffered saline plus Tween 20 (PBS-Tween) before $100 \mu \mathrm{l}$ of an admixture of MAbs to potyvirus epitopes $1+2+3+4+8+10+21 \quad(10,11)$ was added. The plates were incubated for $2 \mathrm{~h}$ at room temperature or overnight at $4^{\circ} \mathrm{C}$, and washed four times with PBS-Tween. Later, $100 \mu \mathrm{l}$ of goat anti-rabbit $\gamma$-globulin conjugate was added and incubated for $1 \mathrm{~h}$ at room temperature. Finally, $100 \mu \mathrm{l}$ of $\mathrm{p}$ nitrophenol phosphatase (Sigma Chemical Co.) diluted in diethanolamine buffer was added to each well. Reactions were stopped with $50 \mu \mathrm{l}$ of $3 \mathrm{M}$ sodium hydroxide, and optical density at $405 \mathrm{~nm}$ determined after $1 \mathrm{~h}$. The positive threshold used was four times the mean of the healthy control value.

Survey of mashua in Ecuador for the occurrence of potyviruses. A survey of 46 accessions of mashua, maintained at the National Institute for Agricultural Research's (INIAP) Santa Catalina Research Station (SCRS), Quito, Ecuador, and plants from 8 fields representing the major production areas in the Ecuadorian highlands, for the presence of $\mathrm{Tt} 4$ - and $\mathrm{Tt}$ 9-like isolates, was carried out during April 1993. Virus testing included both indirect ACPELISA, with an admixture of PTY MAbs described above, and bioassay to $N$. benthamiana and $G$ globosa. For each accession and production field, a composite sample of symptomatic young leaves from a minimum of 5 plants was collected. Leaf samples were triturated in either $\mathrm{CB} / \mathrm{PVP}$ containing $0.2 \%$ DIECA for ACP-ELISA, or in $0.01 \mathrm{M}$ sodium phosphate buffer, $\mathrm{pH}$ 7.0, for bioassay on indicator plants. Sap extracts were diluted 10 -fold and tested using indicator plants as before. Plants were maintained in a greenhouse and observed over a 4-week period for symptom development.

Aphid transmission. Green peach aphids (Myzus persicae (Sulzer)) were reared on curly dock (Rumex crispus L.) in a quarantine greenhouse. Several hundred adults and nymphs were shaken onto moist filter paper and starved for $4 \mathrm{~h}$. Approximately 100 adults and nymphs (3rd and 4th instar) were transferred to detached leaves of T. tuberosum (ECU 1093) and given an acquisition access period (AAP) of $30 \mathrm{~s}$ to 5 min. As soon as aphids probed, they were moved in sets of 25 or more to 3week-old $N$. benthamiana seedlings for a 24-h inoculation access period (IAP). An identical group of green peach aphids was allowed the same period of time to probe on virus-free curly dock, then transferred onto $N$. benthamiana for a 24-h IAP as a control. Plants were sprayed with a dilute solution of malathion ( $O, O$-dimethylphosphorodithioate of diethylmercaptosuccinate; $0.2 \mathrm{~g}$ a.i./liter) and placed on a greenhouse bench for a 30-day observation period. To confirm virus transmission, leaf tissue was bioassayed using healthy $N$. benthamiana as previously described.

\section{RESULTS}

Host range. The host range of all 10 isolates of the unknown potyvirus were identical, with most species being only locally infected (Table 1). Good diagnostic hosts were identified as Chenopodium quinoa L., C. amaranticolor L., and $G$. globosa L. serving as bioassay or local lesion hosts, and $N$. benthamiana as both a diagnostic and propagative host. Isolates $\mathrm{Tt}$ 4 and Tt 9 were selected for further study.

Physical properties. In crude extracts, isolates Tt 4 and $\mathrm{Tt} 9$ were infective after treatment at $50^{\circ} \mathrm{C}$ for $10 \mathrm{~min}$ but not after treatment at $60^{\circ} \mathrm{C}$ for $10 \mathrm{~min}$. The DEP for both isolates was between $10^{-5}$ to $10^{-6}$, and the LIV for both isolates was determined to be 5 days at $20^{\circ} \mathrm{C}$.

Purification and electron microscopy. Purification of the $\mathrm{Tt} 4$ isolate from infected $N$. benthamiana yielded approximately $10 \mathrm{mg}$ of virus per kilogram of fresh weight of leaf tissue, an absorbance maximum of $260 \mathrm{~nm}$, and an $A_{260 / 280}$ of 1.08. In negatively stained preparations, $\mathrm{Tt}$ 4 appeared as flexuous particles 600 to 800 $\mathrm{nm}$, with a modal length of $750 \mathrm{~nm}$ and approximate diameter of $10 \mathrm{~nm}$.

Aphid transmission. The green peach aphid (Myzus persicae) transmitted virus to $N$. benthamiana from $T$. tuberosum accession ECU 1093 infected with isolate Tt 4. Controls were negative. Symptoms on $T$. tuberosum began as vein-clearing by 10 days, and progressed to chlorotic mosaic, followed by leaf deformation, petiole curvature, and necrosis of leaf and stem tissues within 2 weeks.

Polyclonal antibody indirect ELISA. The Tt 4 and Tt 9 isolates reacted positively to PTY-1 MAb and polyclonal antiserum to BCMV and WMV-2, but not to the healthy control or WMV-1, PVY-C, PVA, PMMV, TuMV, LMV, DaMV, TEV, PSMV, MDMV-A and B, and SMV. In reciprocal tests, polyclonal antiserum to the $\mathrm{Tt} 4$ isolate reacted positively in indirect ELISA against isolates of $\mathrm{Tt} 4$, Tt 9, PVY-C, less strongly to TEV and PVA, but not to MDMV-A, MDMV-B, BCMV, DaMV, WMV-1, WMV-2, PMMV, TuMV, LMV, SMV, and PSMV. The Tt 4 and Tt 9 isolates were determined to be closely related strains of the same aphid-transmitted potyvirus. The virus has been tentatively named Tropaeolum mosaic potyvirus (TropMV). 
Detection of unique and potyvirus group-common epitopes. The reactivity patterns of a panel of 26 virus-specific and group-cross reactive MAbs with selected virus isolates from $T$. tuberosum and other potyviruses were compared in ACPELISA. This panel of MAbs has been useful in examining the intra-virus, inter-virus, and intra-group serological relationships among and between diverse potyviruses $(8,9)$.

The reactivity patterns of $\mathrm{Tt} 1, \mathrm{Tt} 2, \mathrm{Tt}$ 4, Tt 9, pepper mottle potyvirus (PepMoVNC), potato potyvirus Y (PVY-3), tobacco etch potyvirus (TEV-PV69), and bean yellow mosaic potyvirus (BYMV-GDD) with 10 of the MAbs are shown in Table 2. The 10 selected MAbs define 10 different potyviral epitopes $(8,9)$. MAbs PTY 1 through PTY 12 each define unique potyvirus group-common epitopes present on 33 distinct potyviruses. MAbs PTY 21 defines a unique epitope shared between specific isolates of BYMV and PepMoV NC.
MAbs PTY 35 defines an epitope shared between 6 of 9 BYMV isolates. The reaction profiles of $\mathrm{Tt} 1$, $\mathrm{Tt} 2$, and $\mathrm{Tt} 9$ are indistinguishable from each other but differ from the profile of $\mathrm{Tt} 4$. Both reactivity profiles are distinct from any of the other potyviruses tested (Table 2 ). The reaction profile of $\mathrm{Tt} 1$, Tt 2, and Tt 9 against the panel of 26 MAbs (data not shown) also are distinct from any of the other potyviruses tested with this panel of MAbs $(8,9)$. The reaction profile of $\mathrm{Tt} 4$ is similar to that of MDMV-A reported in the literature (8), indicating that the epitopes recognized by MAbs PTY 1, 3, and 4 are apparently shared between MDMV-A and isolate Tt 4 .

Survey for potyvirus in mashua in Ecuador. Forty-three of 46 accessions of T. tuberosum at the INIAP's SCRS and plants from all eight production fields surveyed exhibited interveinal chlorosis, leaf cupping, distortion, and stunting symptoms typical for virus infection (data not shown). Of the 46 accessions, 34 tested

Table 2. Differential reactivity of potato virus Y (PTY) monoclonal antibodies with selected virus isolates from Tropaeolum tuberosum (Tt) and other potyviruses in antigen coated plate enzymelinked immunosorbent assay (ELISA) ${ }^{\mathrm{a}}$

\begin{tabular}{lcccccccccc}
\hline & \multicolumn{10}{c}{ PTY monoclonal antibody } \\
\cline { 2 - 11 } Potyvirus $^{\mathbf{b}}$ & $\mathbf{1}$ & $\mathbf{2}$ & $\mathbf{3}$ & $\mathbf{4}$ & $\mathbf{5}$ & $\mathbf{8}$ & $\mathbf{1 0}$ & $\mathbf{1 2}$ & $\mathbf{2 1}$ & $\mathbf{3 5}$ \\
\hline Tt 1 & +++ & - & + & + & + & + & - & - & - & - \\
Tt 2 & +++ & - & + & + & + & + & - & - & - & - \\
Tt 9 & +++ & - & + & + & + & + & - & - & - & - \\
Tt 4 & +++ & - & + & + & - & - & - & - & - & - \\
BYMV-GDD & +++ & +++ & +++ & +++ & - & ++ & $(+)$ & + & +++ & +++ \\
PepMoV-NC & +++ & - & +++ & + & - & - & +++ & ++ & +++ & - \\
PVY-3 & +++ & +++ & - & +++ & - & ++ & +++ & - & - & - \\
TEV-PV69 & +++ & +++ & - & - & - & ++ & ++ & + & - & - \\
MDMV-A & +++ & +++ & - & +++ & - & ++ & - & - & - & - \\
\hline
\end{tabular}

${ }^{a}$ Indirect ELISA using potyvirus-infected plant extracts (final dilution 1:30, wt/vol) diluted in carbonate buffer and direct coating of Nunc ELISA plates. Relative ELISA A405 values after 1-h substrate incubation were $(+++)=>1.2 ;(++)=0.6$ to $1.2 ;(+)=0.6$ to 0.2 ; and $(-)=<0.1$.

${ }^{\mathrm{b}}$ Acronyms Tt 1, Tt 2, Tt 9, and Tt 4 represent Tropaeolum mosaic potyvirus isolates from mashua (Tropaeolum tuberosum) accessions ECU 1145, ECU 1141, ECU 1147, and ECU 1093, respectively. BYMV-GDD = bean yellow mosaic potyvirus strain GDD, PepMoV = pepper mottle virus isolate NC, PVY-3 = potato virus Y strain 3, TEV-PV69 = tobacco etch virus isolate PV69, and MDMV-A = maize dwarf mosaic potyvirus strain A.

Table 3. Incidence of mechanically transmitted potyvirus in Ecuadorian accessions of mashua (Tropaeolum tuberosum) at the National Institute for Agricultural Research (INIAP) Santa Catalina Research Station, Quito, Ecuador as determined by bioassay and antigen coated plate enzyme-linked immunosorbent assay (ACP-ELISA)

\begin{tabular}{lcccc}
\hline & \multicolumn{3}{c}{ Bioassay $^{\mathbf{b}}$} & \\
\cline { 2 - 4 } Sample $^{\mathbf{a}}$ & Nicotiana benthamiana & Gomphrena globosa & ACP-ELISA $^{\mathbf{c}}$ \\
\hline 14 accessions & + & + & + \\
7 accessions & - & + & + \\
10 accessions & + & + & + \\
2 accessions & + & + & - \\
4 accessions & - & - & - \\
2 accessions & + & - & + \\
3 accessions & - & - & - \\
4 accessions & - & &
\end{tabular}

${ }^{a}$ Six to 13 symptomatic plants of each accession were tested; with few exceptions, $100 \%$ of the source plants tested positive.

${ }^{\mathrm{b}}$ Indicator species. Symptoms were as described in Table 1.

${ }^{\mathrm{c}}$ Indirect ELISA, using admixture of MAbs reactive to Tropaeolum mosaic potyvirus $\mathrm{Tt} 4$ and $\mathrm{Tt} 9$ isolates with virus-infected plant extracts (final dilution 1:30, wt/vol) diluted in carbonate buffer and direct coating of Nunc ELISA plates. A positive/negative threshold $A_{405}$ value of 4 times the healthy control was used. positive for TropMV using ACP-ELISA, and 39 accessions tested positive by bioassay to either $N$. benthamiana or G. globosa (Table 3). Four accessions tested negative in both ACP-ELISA and bioassay tests. Composite samples from all eight production fields tested positive for TropMV in ACP-ELISA and bioassay (data not shown).

\section{DISCUSSION}

This work shows that TropMV is widespread among accessions of T. tuberosum at INIAP's SCRS and in all production fields surveyed in the highlands of Ecuador. Because several symptomatic accessions tested negatively in ACP-ELISA and bioassay for TropMV, other viruses are probably present. Results of physical property tests and the determination of particle shape (flexuous rod) and modal length $(750 \mathrm{~nm})$ are consistent with the potyvirus group. TropMV appears to be a unique member of the potyvirus group that shares epitopes with PVY-C, TEV, PVA, WMV-2, and BCMV; and, in the case of Tt 9, cryptotopes with MDMV-A.

Tropaeolum mosaic potyvirus is readily transmitted mechanically; and, because mashua is vegetatively propagated via tubers, TropMV may be spread during propagation of the crop. It is reasonable to assume that TropMV has been spread among locations in the Andean highlands by infected tubers. As no attempt has been made to eliminate viruses from this crop, it is possible that TropMV has been accumulating in mashua germplasm for centuries. Our data indicates that the majority (more than 50\%) of mashua germplasm accessions are contaminated by TropMV and that all production fields surveyed, where tubers are often saved from year to year, contained infected plants. While aphids are generally not present at the higher elevation range of mashua production, aphids were noted on weeds and on mashua plants at the lower elevation range of the crop (personal observation). As $C$. quinoa is a common weed in the Andean highlands and is known to be a host for TropMV (Table 1), it may act as a reservoir for the virus. Control of aphids and weed species that may act as virus reservoirs could be an important means to manage the disease for growers if mashua germplasm is to be maintained virus-free for prolonged periods of time.

We do not known if TropMV is the same as the virus described by Delhey and Monasterios (4) from mashua in Bolivia, because their study did not include the physical properties, host range, or serological data. Further, they made no comment as to the incidence of infection within mashua. Our results are the first report of the incidence and partial characterization of a new potyvirus, tentatively named Tropaeolum mosaic potyvirus, infecting mashua in the Andean highlands. Because of the lack of 
definitively virus-free mashua germplasm, TropMV was not returned to mashua to determine if it in fact causes the symptoms described in this paper.

To date, no attention has been given to the development of virus-free mashua and the effect of TropMV on mashua growth and productivity. Subsequent work in our laboratories has demonstrated that virusfree germplasm can be generated via the culture of apical domes, and that the growth and productivity of virus-infected mashua may be adversely affected under certain conditions (15). Four virus-free accessions have been developed and are available to Ecuadorian farmers. Mashua is being grown in the United States Pacific Northwest and in New Zealand (10) and has potential for commercialization. The widespread occurrence of TropMV in Ecuador, and the possibility of additional viruses occurring within germplasm collections, must be addressed if plant material is to move freely between countries and mashua is to be successfully commercialized.

\section{ACKNOWLEDGMENTS}

We thank R. Jordan and J. Hammond at USDAARS BARC West for monoclonal antibody testing and suggestions on the research, and A. Stone at USDA-ARS, Fort Detrick, for laboratory assistance.

\section{LITERATURE CITED}

1. Beemster, A. B. R. 1960. Verslag van de werkzaamheden vande virologische afdeling. Algemene onderzoekingen over plantenvirusziekten. Jversl. Inst. Plziektenk. Onderz. 83-88.

2. Bhargava, K. S., and Joshi, R. D. 1959. Observations of a virus disease of a garden nasturtium (Tropaeolum majus L.) occurring in Naini Tal. J. Indian Bot. Soc. 38:379-382.

3. Bisht, N. S. 1962. Aphis gosspii Glov. as vector of nasturtium ringspot virus. Curr. Sci. 31:23-24.

4. Delhey, R., and Monasterios T. 1977. A mosaic disease of isanu, Tropaeolum tuberosum) from Bolivia. Z. Pflanzenkr. Pflanzenschutz 84:224-231.

5. Hammond, J., and Lawson, R. G. 1988. An improved purification procedure for preparing potyviruses and cytoplasmic inclusions from the same tissue. J. Virol. Methods 20:203217.

6. Horvath, J., and Szirmai, J. 1975. Tropaeolum majus L., a natural host plant of nasturtium ringspot virus in Hungary. Phytopathol. Z. 82:122-127.

7. Jensen, D. D. 1959. Nasturtium mosaic, a virus disease of Tropaeolum majus L. In California. Phytopathology 40:967.

8. Jordan, R. 1992. Potyviruses, monoclonal antibodies, and antigenic sites. W. W. Barnett, ed. Arch Virol. [Suppl. 5]:81-95.

9. Jordan, R. L., and Hammond, J. 1991. Comparison and differentiation of Potyvirus isolates and identification of strain-, virus-, subgroup-specific and Potyvirus group-common epitopes using monoclonal antibodies. J. Gen. Virol. 72:25-36.

10. National Research Council. 1989. Lost crops of the Incas; little known plants of the Andes with promise for worldwide cultivation. National Academy Press, Washington, DC.

11. Schmelzer, K. 1960. Untersuchungen uber das ringmosaik virus der kapuzinerkresse. Z. Pflanzenkrankh. 67:193-210.

12. Severin, H. H. P., and Freitag, J. H. 1933. List of ornamental flowering plants naturally infected with curly top or yellow diseases in California. Plant Dis. Rep. 17:1-2.

13. Silberschmidt, K. 1953. Studies on a mosaic of nasturtium occurring in Brazil. Phytopathology 43:304-308.

14. Smith, K. M. 1950. Some new virus diseases of ornamental plants. J. R. Hortic. Soc. 75:350-353.

15. Soria, S. L., Toboada, C., Kitto, S. L, Rojas, R. Damsteegt, V. D., and Evans, T. A. Effect of Potyvirus infection on mashua (Tropaeolum tuberosum Ruiz \& Pavon) in vitro and in the field. HortScience. In press.

16. Uschdraweit, H. A., and Valentin, H. 1956 Das tabakmauchevirus an zierpflanzen. Nachrbl dt. Pflschutzdienst, Braunschweig 8:132-133.

17. Walkey, D. G. A. 1991. Applied plant virology. 2nd edition. Chapman Hall, London. 